\title{
EDITORIAL INTERAÇÕES CONTEMPORÂNEAS ENTRE O RURAL E O URBANO
}

Joaci de S. Cunha *

Ângela Borges **

O derradeiro quadrimestre do ano de 2020 se encerra sob o signo da crise sanitária da Covid-19 em meio à crise sistêmica, agora em metástase e avançando sobre a democracia política das sociedades, seja aqui ou alhures. Entre nós, as ameaças de novos golpes se sucedem sob o patrocínio direto da Presidência, e eleições ou apoio popular podem impunemente ser compradas com fartos aportes orçamentários. Nos EUA, 2020 deixou desenhado a tentativa de golpe por D. Trump. Nesse ano, a crise de reprodução da sociabilidade capitalista extrapolou da dimensão socioeconômica e ambiental para a esfera da biossegurança da humanidade. Indo além, mortos por Covid-19 somaram-se às vítimas da fome, desnutrição e doenças da miséria em todos os continentes. Mas, sobretudo, tais crises associadas afetam agora a própria estabilidade do regime político de dominação, pautado na democracia do capital, com ameaças fascistas ao Sul e ao Norte.

De fato, nas últimas décadas, a acumulação de capital, num processo de contínua destruição, criação e recriação, tanto produtiva quanto de relações sociais e valores, aprofunda desigualdades de toda ordem nos vários continentes, além de acentuar a destruição do meio ambiente e das condições, modos de vida e culturas que não se submetem à sua lógica.

Naturalmente, em 2020, este processo estrutural de longa duração encontrou na conjuntura aberta pela pandemia de coronavírus condições sanitárias extremamente

\footnotetext{
* Advogado, doutor em História pela Universidade Federal da Bahia (UFBA), pós-doutor (2020) pelo Programa de Políticas Sociais e Cidadania da Universidade Católica do Salvador, assessor do Centro de Estudos e Ação Social (CEAS) e coeditor da revista Cadernos do CEAS. É autor de diversos artigos e capítulos publicados, respectivamente, em revistas e livros. Pela Edufuba (2017) assina O fazer político da Bahia na República (19001930). Matriz das relações entre Estado, corporações e políticos.

** Doutora em Ciências Sociais, Profa. Adjunta da Universidade Católica do Salvador, Programa de Pósgraduação em Políticas Sociais e Cidadania. 
favoráveis para potencializar seus efeitos nefastos. O SARS-Cov2 pode não distinguir ou preferir corpos. Mas a democracia das crises atuais acaba aí. Porque os mais pobres de todos os quadrantes, amontoados nas favelas urbanas e rurais do planeta, não tem acesso aos mesmos recursos médicos ou às futuras vacinas e, principalmente, têm os seus meios de vida destruídos em primeiro plano, não raro com a ação ou omissão genocida de governos.

Tal processo, no entanto, encontra resistências das populações e classes sociais vitimizadas, de comunidades e de movimentos sociais globais, nacionais e locais. A divulgação de análises críticas desses processos, necessariamente de caráter interdisciplinar e intersetorial, constitui-se no principal objetivo dos Cadernos do CEAS, como tivemos a oportunidade de discuti-los em vários artigos nas edições dos últimos anos.

Enfim, em nossa perspectiva, as consequências da pandemia por Covid-19 estão intrinsecamente ligadas às crises dos modos de produzir, distribuir, consumir e viver do capitalismo; atingem todos os países, cobram um preço elevadíssimo em vidas humanas e sofrimentos sem limites e explicitam o caráter antissocial desse modo de produção e o tipo de sociedade que ele engendra, incapaz de assegurar o bem comum.

Por assim entender, fomentar e divulgar a livre reflexão sobre essa realidade alimentaram os Cadernos do CEAS em sua mais que cinquentenária trajetória. Manter-se como um espaço para discussão dos desafios hoje colocados para a humanidade e, especialmente, aos seus segmentos mais vulneráveis, continuam sendo seu desiderato.

Desse modo, ao encerrar 2020, nossa revista cumpriu o seu papel de ter feito circular suas três edições ordinárias, publicando trinta e quatro (34) textos, entre artigos, apresentações, resenhas, documentos e editoriais, com contribuições críticas de cinquenta e três (53) pesquisadores de diversas instituições de Norte a Sul do país e de quase todos os quadrantes da América Latina.

Nessa toada, a primeira edição do ano priorizou o debate dobre a Amazônia, vítima dos crimes ambientais orquestrados sobre as vistas do governo Bolsonaro, destacando a preocupação e iniciativas da Igreja Católica, sob a liderança Papa Francisco. Na edição seguinte (N. 250), a América Latina no seu labirinto foi o tema com o qual mobilizamos colaboradores de sete países para passar em revista crítica a história, problemas e dilemas recentes do nosso continente. Nessas edições, também estiveram presentes os temas da crise sanitária e da pandemia de Covid-19, que perpassaram por boa parte das discussões. Neste número (251), disponibilizamos aos leitores o Dossiê O rural e o urbano em interação, 
coordenado e apresentado pelas professoras do Programa de Pós-graduação em Planejamento Territorial e Desenvolvimento Social da Universidade Católica do Salvador, Cristina Alencar e Maina Pirajá, com contribuições interdisciplinares de pesquisadores de várias instituições brasileiras. Completa esta edição o artigo Crises, disputas e resistências: os territórios tradicionais das comunidades pesqueiras e quilombolas da Ilha de MARÉ - BA, de Kássia Aguiar Norberto Rios, no qual a autora apresenta resultados de sua pesquisa, dialogando diretamente com a temática do Dossiê.

Que 2021 não repita 2020, embora não esteja no horizonte sentir as alegrias, mesmo que ilusórias, de um ano novo. 